\title{
Efficacy and safety of intravenous pamidronate infusion for treating osteoporosis in children and adolescents
}

Ji-Hee Yoon,

Yunha Choi,

Yena Lee,

Han-Wook Yoo,

Jin-Ho Choi

Department of Pediatrics, Asan Medical Center Children's Hospital, University of Ulsan College of Medicine, Seoul, Korea
Received: 16 July, 2020

Revised: 30 August, 2020

Accepted: 9 September, 2020

\section{Address for correspondence:}

\section{Jin-Ho Choi}

Department of Pediatrics, Asan Medical Center Children's Hospital, University of Ulsan College of Medicine, 88, Olympic-ro 43-Gil, SongpaGu, Seoul 05505, Korea

Email: jhc@amc.seoul.kr

https://orcid.org/0000-0003-11967826
Purpose: Osteoporosis is a skeletal disorder characterized by reduced bone mass that results in increased risk of fractures. Pediatric osteoporosis can be caused by monogenic diseases, chronic diseases, and/or their treatment. This study was performed to investigate the effect of pamidronate infusion on osteoporosis in children and adolescents.

Methods: This study included 13 unrelated pediatric patients (10 males and 3 females) whose bone mineral density (BMD) $z$-score was $<-2.0$. Pamidronate was administered intravenously at a dosage of $1 \mathrm{mg} / \mathrm{kg}$ for 3 consecutive days every 4 months. Clinical and biochemical findings were reviewed retrospectively. The BMD values of the lumbar spine and femoral neck were assessed by dual energy $\mathrm{x}$-ray absorptiometry at baseline and annually.

Results: The underlying diseases were immobilization (62\%), inflammatory bowel disease (23\%), protein-losing enteropathy (8\%), and idiopathic juvenile osteoporosis (8\%). The mean age at the start of treatment was $12.7 \pm 4.3$ years. Duration of treatment ranged from 12-50 months. The baseline height-standard deviation score (SDS) and weight-SDS were $-2.01 \pm 2.08$ and $-2.60 \pm 1.62$, respectively. The lumbar spine BMD $z$-scores improved significantly after 1 year of pamidronate treatment, but the femoral neck BMD $z$-scores did not. However, both $z$-scores had significantly increased by the end of treatment.

Conclusion: This study demonstrated that pamidronate treatment increased BMD in pediatric patients with osteoporosis with no significant adverse events. Further studies are required to better define the long-term efficacy and safety of pamidronate therapy in a large number of pediatric patients.

Keywords: Bisphosphonate, Bone mineral density, Osteoporosis, Pamidronate

\section{Highlights}

Pamidronate has been used to treat pediatric osteoporosis, while the efficacy and safety remain uncertain. This study demonstrated that pamidronate treatment significantly increased bone mineral density in pediatric patients with osteoporosis without any severe adverse event.

\section{Introduction}

Osteoporosis is a disorder of the bone matrix that is accompanied by low bone density. It is characterized by reduced bone mass and deterioration of bone micro-architecture that increase the risk of fractures. ${ }^{1)}$ The International Society for Clinical Densitometry recommends a diagnosis of pediatric osteoporosis if the patient has one or more vertebral compression fractures without evidence of local disease or high-energy trauma. In the 
absence of vertebral compression fractures, osteoporosis can be diagnosed based on the presence of both a clinically significant fracture history and bone mineral density (BMD) $z$-score $\leq-2.0$. A clinically significant fracture history is defined as one or more of the following: (1) 2 or more long bone fractures by the age of 10 years or (2) 3 or more long bone fractures at any age up to 19 years. ${ }^{2)}$ In children, osteoporosis is categorized into primary and secondary forms. Primary osteoporosis results from intrinsic defects in matrix formation and is usually a hereditary disease, such as osteogenesis imperfecta. ${ }^{3)}$ Secondary osteoporosis often is caused by chronic diseases and/or their treatment and arises due to lack of exercise, malnutrition, malabsorption, hormonal imbalance, and medications, such as glucocorticoids or immunosuppressive treatments. ${ }^{4,5)}$

Osteoporosis can be treated with bisphosphonates, which are synthetic analogues of inorganic pyrophosphate. These compounds reduce the viability and activity of osteoclasts and induce apoptosis. They also increase the activity of osteoblasts, leading to indirect inhibition of osteoclasts by production of osteoclast inhibitors. Bisphosphonates are powerful suppressors of bone resorption and enable preservation of bone microarchitecture and trabecular bone. ${ }^{6)}$ One type of bisphosphonate, pamidronate (3-amino-1-hydroxypropylidene-bisphosphonate), is administered intravenously and is used widely as an effective and safe treatment for osteoporosis in children. ${ }^{7,8)}$ Several previous studies have shown that cyclic intravenous treatment with pamidronate improved BMD in children with osteoporosis. For example, pamidronate administration in patients with severe osteogenesis imperfecta resulted in a significant reduction in incidence of fractures and promoted an increase in BMD. ${ }^{8)}$ Similarly, in quadriplegic children with osteoporosis, pamidronate therapy increased lumbar spine BMD compared to a placebo group. ${ }^{9)}$ Pamidronate therapy also increased BMD in patients treated with high doses of steroids due to renal or rheumatoid disease. ${ }^{10)}$ In a Korean study, monthly intravenous pamidronate therapy decreased the frequency of fracture and increased BMD of the femur and lumbar spine in patients with osteogenesis imperfecta and osteosarcoma. $^{11,12)}$

While intravenous pamidronate has been used commonly to treat pediatric osteoporosis, the efficacy and safety of oral bisphosphonates in children remain uncertain. ${ }^{13,14)}$ However, no definite pamidronate treatment guidelines have been established for dose or interval in children because most previous studies have included only small numbers of patients and short-term treatment periods. Therefore, the aim of the present study was to investigate the effects of pamidronate infusion in children and adolescents with osteoporosis.

\section{Materials and methods}

\section{Participants}

This study included 13 unrelated patients (10 males and 3 females) who were treated with pamidronate between August
2006 and May 2020 at the Department of Pediatrics of Asan Medical Center Children's Hospital in Seoul, Korea. The inclusion criteria were as follows: (1) age $<18$ years at diagnosis of osteoporosis; (2) initial BMD $z$-score of the lumbar spine or femur neck $\leq-2.0$ along with high risk of fractures due to underlying diseases and/or their treatment; and (3) a duration of pamidronate treatment of at least 12 months. Patients with osteoporosis caused by genetic syndromes, such as osteogenesis imperfecta, were excluded from this study.

\section{Methods}

The patients were hospitalized and treated intravenously with $1 \mathrm{mg} / \mathrm{kg}$ of pamidronate for 3 consecutive days every 4 months. Pamidronate was diluted in $250-500 \mathrm{~mL}$ of isotonic saline (concentration $<0.1 \mathrm{mg} / \mathrm{mL}$ ). The patients were supplemented daily with $600 \mathrm{mg}$ of elemental calcium and 400 units of 25-dihydroxycholecalciferol $\left(25(\mathrm{OH})_{2} \mathrm{D}_{3}\right)^{8}{ }^{8}{ }^{8}$

The medical records from every pamidronate infusion visit were reviewed retrospectively to obtain patient height, weight, and history of fractures and for biochemical parameters of serum calcium, phosphorus, alkaline phosphatase, intactparathyroid hormone $(\mathrm{PTH})$, and $25(\mathrm{OH})_{2} \mathrm{D}_{3}$. The $z$-scores of the height and weight of each child were expressed according to the normative data for Korean children. ${ }^{15)}$ New fractures that occurred during treatment were confirmed by simple radiographs.

The BMD values of the femoral neck and lumbar spine (L1-4) were measured by dual energy $\mathrm{x}$-ray absorptiometry (Lunar Corp., Madison, WI, USA) at baseline and again annually. The BMD $z$-scores were adjusted by age- and sex-matched standards for Korean children. ${ }^{16,17)}$ The Korean reference data for children aged $\geq 10$ years were measured using the Hologic system. Therefore, the BMD data were converted using the following formulas: (1) lumbar spine BMD according to the Hologic system $=0.837 \times$ lumbar spine BMD of the Lunar system +0.021 or (2) femoral neck BMD from the Hologic system $=0.913 \times$ femoral neck BMD obtained by the Lunar system $-0.080{ }^{18)}$

\section{Statistical analysis}

Statistical analysis was performed with the IBM SPSS Statistics ver. 24.0 (IBM Co., Armonk, NY, USA). Changes in BMD $z$-scores, height, weight, and biochemical parameters after pamidronate treatment were analyzed using the Wilcoxon signed rank test. Spearman correlation analysis was used to analyze the correlation between treatment duration and BMD changes. $P$-values $<0.05$ were considered statistically significant. Each measurement value was expressed as mean \pm standard deviation. 


\section{Results}

\section{Clinical characteristics at the start of pamidronate treatment}

The mean age at the start of pamidronate treatment was $12.7 \pm 4.3$ years (range, $5.8-17.8$ years) (Table 1 ). The mean age at diagnosis of underlying disease was $4.8 \pm 6.1$ years (range, $0-15.8$ years). Eight patients (62\%) had osteoporosis caused by immobilization due to a brain or spine injury $(\mathrm{n}=7)$ or to severe restrictive lung disease $(\mathrm{n}=1)$. Four patients $(31 \%)$ had a history of long-term glucocorticoid treatment for inflammatory bowel disease $(n=3)$ or protein-losing enteropathy $(n=1)$. The mean duration of steroid treatment was 9.6 months (range, 5-19 months). Participant No. 12 initially presented with low back pain and multiple compression fractures of the thoracolumbar vertebrae. He did not manifest any abnormal laboratory findings or phenotypes that suggested genetic defects (such as bone deformity, blue sclera, hearing loss, or dentinogenesis imperfecta), so the patient was diagnosed with idiopathic juvenile osteoporosis (IJO). Seven patients (54\%) were in a bedridden state, and all had a history of brain or spine injury. Five patients (38\%) had a previous history of fracture that was confirmed by simple radiographs before treatment. The baseline height-SDS was $-2.01 \pm 2.08$, and the baseline weightSDS was $-2.60 \pm 1.62$. The baseline lumbar spine BMD $z$-score was $-3.8 \pm 1.4$, while the femur neck BMD $z$-score was $-5.7 \pm 2.4$.

\section{Efficacy of pamidronate therapy}

The duration of treatment ranged from 12-50 months (mean, $25.9 \pm 11.9$ months). At 1 year after conclusion of treatment, the height-SDS and weight-SDS had not changed significantly
( $P=0.345$ and $P=0.600$, respectively). The lumbar spine BMD $z$-score improved significantly after 1 year of pamidronate treatment, from $-3.8 \pm 1.4$ to $-2.6 \pm 1.2(P=0.002)$. The femur neck BMD $z$-score increased from $-5.7 \pm 2.4$ to $-4.5 \pm 2.4$ at 1 year after the end of pamidronate treatment; however, this change was not statistically significant $(P=0.082)$ (Fig. 1$)$. No significant changes were detected in the biochemical parameters of serum calcium, phosphorus, alkaline phosphatase, intact- $\mathrm{PTH}$, and $25(\mathrm{OH})_{2} \mathrm{D}_{3}$ levels (Fig. 2).

At the end of treatment, the lumbar spine BMD $z$-score was $-1.6 \pm 1.9$, and the femur neck BMD $z$-score was $-3.6 \pm 3.0$; these scores were significantly improved compared to baseline ( $P=0.001$ and $P=0.029$, respectively), although duration of treatment varied (Fig. 1). The lumbar spine BMD $z$-scores increased depending on duration of pamidronate treatment

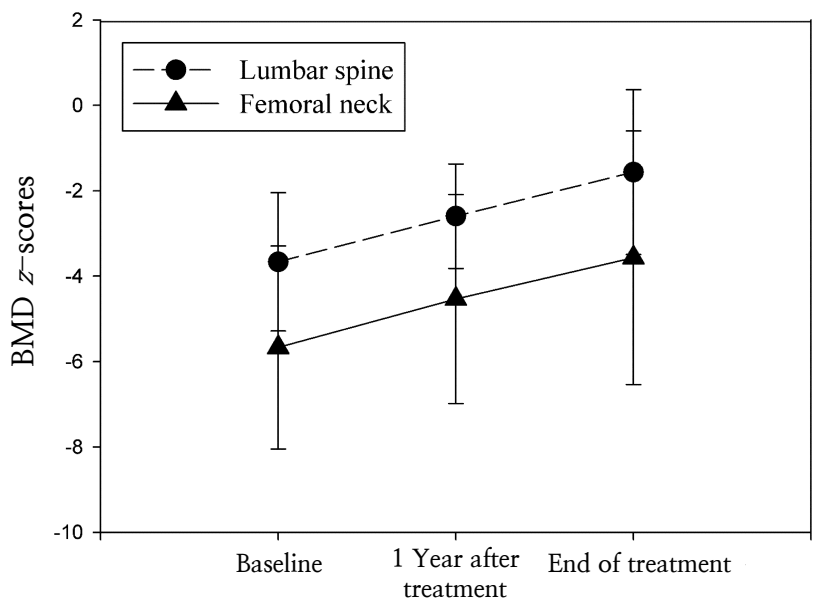

Fig. 1. Changes in lumbar spine and femoral neck bone mineral density (BMD) $z$-scores in patients with osteoporosis at 1 year after beginning treatment with pamidronate and at the end of treatment.

Table 1. Clinical characteristics of patients with osteoporosis at baseline and the end of treatment

\begin{tabular}{|c|c|c|c|c|c|c|c|c|c|c|}
\hline \multirow{2}{*}{$\begin{array}{l}\text { Subject } \\
\text { No. }\end{array}$} & \multirow{2}{*}{ Sex } & \multirow{2}{*}{ Underlying disease } & \multirow{2}{*}{$\begin{array}{c}\text { Age at first } \\
\text { dose (yr) }\end{array}$} & \multirow{2}{*}{$\begin{array}{l}\text { Follow-up } \\
\text { duration } \\
\text { (mo) }\end{array}$} & \multicolumn{2}{|c|}{ Baseline BMD } & \multirow{2}{*}{$\begin{array}{l}\text { No. of } \\
\text { fractures } \\
\text { before } \\
\text { treatment }\end{array}$} & \multicolumn{2}{|c|}{$\begin{array}{l}\text { BMD at the end } \\
\text { of treatment }\end{array}$} & \multirow{2}{*}{$\begin{array}{l}\text { No. of } \\
\text { fractures } \\
\text { after } \\
\text { treatment }\end{array}$} \\
\hline & & & & & $\begin{array}{l}\mathrm{LS} \\
(\mathrm{L} 1-4)\end{array}$ & FN & & $\begin{array}{c}\mathrm{LS} \\
(\mathrm{L} 1-4)\end{array}$ & FN & \\
\hline 1 & $\mathrm{~F}$ & Ulcerative colitis & 17.8 & 17 & -3.2 & -1.9 & 0 & -2.2 & -1.2 & 0 \\
\hline 2 & M & Hypoxic ischemic encephalopathy & 13.5 & 50 & -2.5 & -4.1 & 2 & -0.4 & -5.1 & 0 \\
\hline 3 & $\mathrm{~F}$ & Intraventricular hemorrhage, diastematomyelia & 6.5 & 30 & -6.3 & -8.6 & 0 & -0.7 & -0.9 & 0 \\
\hline 4 & M & Crohn disease & 17.5 & 23 & -2.9 & -3.5 & 0 & -2.6 & -3.0 & 0 \\
\hline 5 & M & Spinal dysraphism & 13.3 & 40 & -2.3 & -4.8 & 1 & 0.1 & -4.0 & 1 \\
\hline 6 & M & Intractable epilepsy & 16.4 & 12 & -2.3 & ND & 0 & -1.8 & ND & 0 \\
\hline 7 & M & Intractable epilepsy & 5.8 & 32 & -3.0 & -7.3 & 3 & 0.4 & -1.8 & 0 \\
\hline 8 & $\mathrm{~F}$ & Crohn disease & 14.9 & 28 & -4.4 & -4.1 & 0 & -3.5 & -4.5 & 0 \\
\hline 9 & M & Hypoxic ischemic encephalopathy & 8.8 & 25 & -3.3 & -5.4 & 0 & 1.6 & 1.1 & 0 \\
\hline 10 & M & Severe restrictive lung -disease & 14.6 & 25 & -3.8 & -5.0 & 0 & -1.5 & -3.0 & 0 \\
\hline 11 & M & Cerebral palsy & 15.9 & 12 & -4.7 & -8.4 & 0 & -4.3 & -7.9 & 0 \\
\hline 12 & M & Idiopathic juvenile osteoporosis & 12.8 & 42 & -4.5 & ND & 3 & -0.3 & ND & 0 \\
\hline 13 & M & $\begin{array}{l}\text { Functional single ventricle, protein losing } \\
\text { enteropathy }\end{array}$ & 6.9 & 14 & -6.5 & -9.3 & 1 & -5.0 & -8.9 & 0 \\
\hline
\end{tabular}

BMD, bone mineral density; FN, femur neck; LS, lumbar spine; ND, not done. 

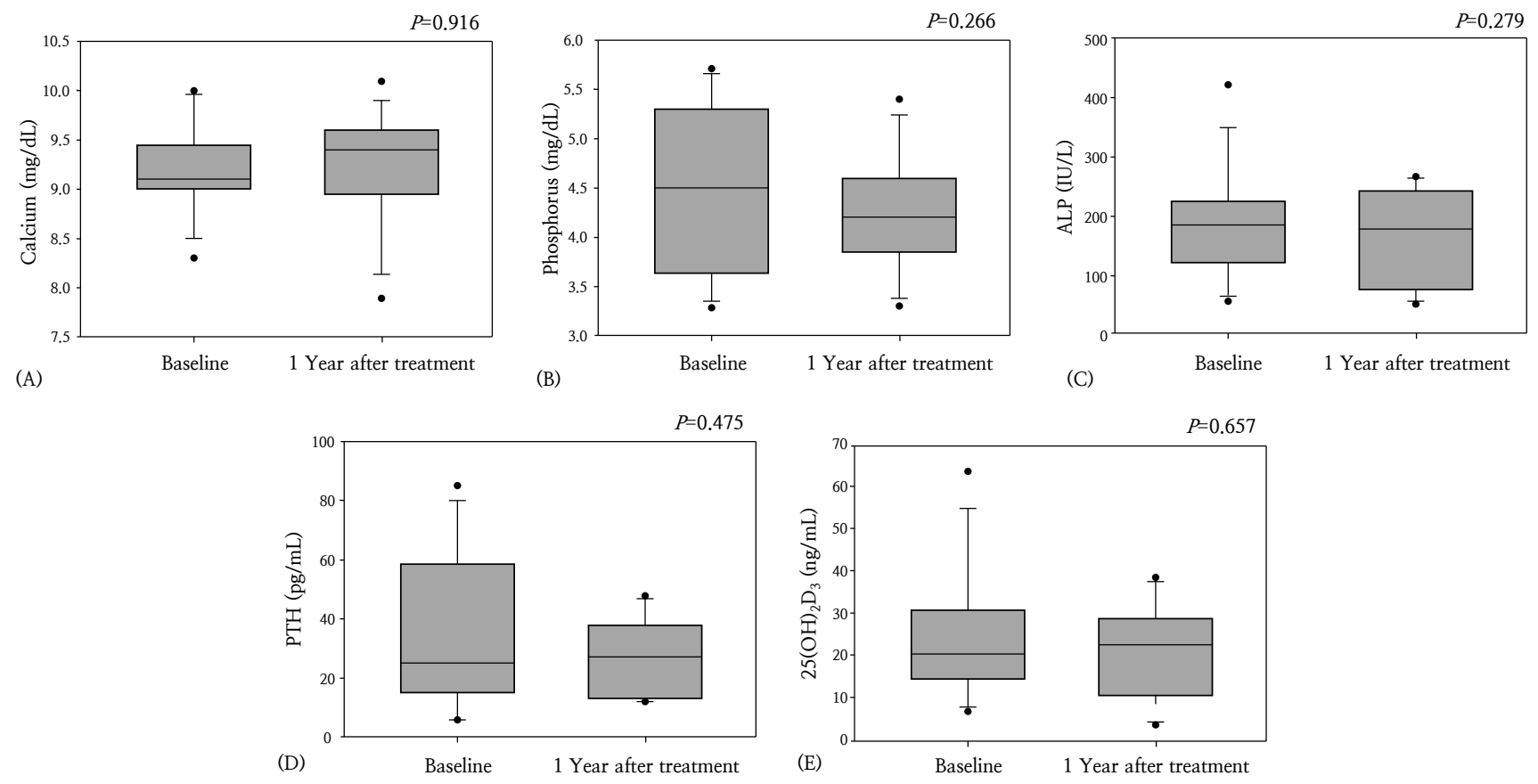

Fig. 2. Changes in biochemical markers in patients with osteoporosis during pamidronate therapy. (A) Calcium, (B) phosphorus, (C) alkaline phosphatase (ALP), (D) parathyroid hormone $(\mathrm{PTH})$, (E) 25-dihydroxycholecalciferol $\left(25(\mathrm{OH})_{2} \mathrm{D}_{3}\right)$.

$(r=0.650, P=0.016)$, but the femoral neck BMD $z$-scores did not show significant changes $(r=0.123, P=0.718)$.

The femoral neck BMD $z$-scores decreased 1 year after treatment in 3 patients (participant Nos. 2, 5, and 8); 2 of them were bedridden due to hypoxic ischemic encephalopathy (participant No. 2) or spinal dysraphism (participant No. 5). Participant No. 5 experienced a fracture of the right proximal femur shaft 4 months after initiation of pamidronate treatment. This patient also had a history of left femoral neck fracture without trauma 4 months prior to starting pamidronate treatment. His femoral neck BMD $z$-score had characteristically worsened 1 year after treatment with pamidronate from -4.8 to -5.8. However, 3 years after initiating pamidronate treatment, his femur neck BMD $z$-score improved to -3.9. No additional fractures occurred thereafter.

In 4 patients (participant Nos. 3, 5, 9, and 12), the lumbar spine and femoral neck BMD values were obtained after discontinuation of pamidronate treatment. Participant No. 3 showed a persistent increase in BMD $z$-scores of the lumbar spine (-0.3) and femoral neck (0.0) 2 years after discontinuation of pamidronate treatment. In participant Nos. 5 and 9, the lumbar spine and femoral neck BMD $z$-scores were maintained within the normal range both 1 year and 2 years after discontinuing pamidronate. In participant No. 12, who had $\mathrm{IJO}$, the lumbar spine BMD $z$-score at the end of treatment was -0.3 ; however, the femoral BMD $z$-score was -2.8 , and it had improved to -1.2 when assessed 5 years after discontinuation of pamidronate.

\section{Adverse events due to pamidronate therapy}

Mild fever occurred in 5 patients (38\%) during the first pamidronate infusion, but fever was reduced with antipyretics. Two patients (participant Nos. 4 and 12) experienced nausea and vomiting. One patient (participant No. 5) reported a mild headache, and one (participant No. 12) had a skin rash; all these side effects were relieved by supportive treatment. These adverse events only occurred at the time of the first treatment, and no additional side effects arose during the second cycle of pamidronate therapy.

\section{Discussion}

This study confirmed the safety and efficacy of intravenous pamidronate as a treatment to increase lumbar spine and femur neck BMD $z$-scores in pediatric patients with osteoporosis. The lumbar spine BMD $z$-scores increased in all 13 patients according to duration of pamidronate treatment. Femur neck BMD $z$-scores showed no significant increase at 1 year after treatment. In 3 patients, femur neck BMD $z$-scores had decreased at 1 year after treatment; 2 of these patients were bedridden. Their bedridden state could have contributed to the persistently low BMD $z$-scores of the femoral neck. However, their femoral neck BMD $z$-scores increased significantly at the end of treatment compared to baseline scores.

Osteogenesis imperfecta is the most prevalent form of primary osteoporosis, with an incidence of $1 / 25,000$ births. ${ }^{19)}$ Recent advances in the molecular genetics of osteoporosis have 
decreased diagnosis of $\mathrm{IJO}^{20)}$ The major causes of osteoporosis in the patients in the present study were immobilization and glucocorticoid treatment. Immobilization and muscle atrophy due to brain or spinal cord injuries reduce mechanical stimulation of the bones, which increases bone resorption and reduces bone formation. ${ }^{21)}$ Glucocorticoids inhibit bone formation by decreasing the number of osteoblasts while stimulating osteoclast proliferation. Glucocorticoids also decrease serum calcium level by decreasing intestinal calcium absorption and increasing renal calcium excretion. ${ }^{7}$ Among 89 pediatric patients with chronic illness and secondary osteoporosis, $40 \%$ had neuromuscular disorders, $24 \%$ had glucocorticoid-treated disorders, and $9 \%$ had childhood cancers. ${ }^{4)}$

Several previous studies on pediatric osteoporosis using pamidronate have shown favorable outcomes (Table 2). For example, patients with cerebral palsy responded to intravenous pamidronate treatment (administered for 3 consecutive days every 4 months for 12- to 18 -month period) with increases in BMD of the lumbar spine ranging from $-4.1 \pm 1.1$ to $-2.5 \pm 0.6$ (an increase of $65.7 \% \pm 55.2 \%$ ) and of the femur from $-4.0 \pm 1.1$ to $-2.1 \pm 2.5$ (an increase of $47.4 \% \pm 39.0 \%$ ). ${ }^{22)}$ Patients with IJO responded to long-term pamidronate treatment (with a mean duration of $7.3 \pm 1.1$ years) with progressive increase in lumbar BMD compared to untreated patients $(P<0.05)$ (Table 2) ${ }^{23)}$ The usual dosage of intravenous pamidronate was $1-1.5 \mathrm{mg} / \mathrm{kg} /$ day for 3 consecutive days. ${ }^{24)}$ Lower doses of pamidronate $(0.75$ $\mathrm{mg} / \mathrm{kg} /$ day for 2 days) increased BMD in patients with severe spastic quadriplegic cerebral palsy. ${ }^{25)}$ Similarly, in Korea, a low dose of pamidronate $(0.5 \mathrm{mg} / \mathrm{kg} /$ day for 3 days $)$ was effective in pediatric patients with secondary osteoporosis caused by hematologic malignancy, autoimmune disease, and epilepsy. A

Table 2. Previous studies of pamidronate treatment for pediatric osteoporosis

\begin{tabular}{|c|c|c|c|c|c|c|c|c|}
\hline \multirow[b]{2}{*}{ Study } & \multirow[b]{2}{*}{ Dose of pamidronate } & \multirow{2}{*}{$\begin{array}{c}\text { No. of } \\
\text { patients }\end{array}$} & \multirow[b]{2}{*}{ Diagnosis } & \multicolumn{3}{|c|}{ Change in BMD z-scores } & \multirow{2}{*}{$\begin{array}{l}\text { Changes in } \\
\text { biochemical marker }\end{array}$} & \multirow[b]{2}{*}{ New fractures } \\
\hline & & & & Site & $\begin{array}{l}\text { Baseline, } \\
\text { mean } \pm S D\end{array}$ & $\begin{array}{c}\text { Final, } \\
\text { mean } \pm S D\end{array}$ & & \\
\hline $\begin{array}{l}\text { Glorieux et al. } \\
\text { (1998) }\end{array}$ & $\begin{array}{l}1 \mathrm{mg} / \mathrm{kg} / \text { day for each of } \\
3 \text { days every 4-6 mo for } \\
1.3-5.0 \mathrm{yr}\end{array}$ & 30 & $\begin{array}{l}\text { Osteogenesis } \\
\text { imperfecta }\end{array}$ & LS & $-5.3 \pm 1.2$ & $-3.4 \pm 1.5$ & $\begin{array}{l}\text { Decreased serum ALP, } \\
\text { urine calcium, NTx }\end{array}$ & $\begin{array}{l}\text { Decreased } \\
\text { incidence by } 1.7 / \\
\text { yr }\end{array}$ \\
\hline $\begin{array}{l}\text { Henderson et } \\
\text { al. }^{9)}(2002)\end{array}$ & $\begin{array}{l}1 \mathrm{mg} / \mathrm{kg} / \text { day for } 3 \\
\text { consecutive days every } 3 \\
\text { mo over } 18 \text { mo }\end{array}$ & 6 & $\begin{array}{l}\text { Nonambulatory c } \\
\text { hildren with severe } \\
\text { CP }\end{array}$ & $\begin{array}{l}\mathrm{LS} \\
\mathrm{DF}\end{array}$ & $\begin{array}{l}-3.4 \pm 0.4 \\
4.0 \pm 0.6\end{array}$ & $\begin{array}{l}-2.2 \pm 0.4 \\
-1.8 \pm 1.0\end{array}$ & $\begin{array}{l}\text { Decreased serum } \\
\text { N-telopeptides }\end{array}$ & None \\
\hline $\begin{array}{l}\text { Grissom et al. }^{22)} \\
(2005)\end{array}$ & $\begin{array}{l}1 \mathrm{mg} / \mathrm{kg} / \text { day for } 3 \\
\text { consecutive days every } 4 \\
\text { mo over } 12-18 \mathrm{mo}\end{array}$ & 12 & $\begin{array}{l}\text { Spastic quadriplegic } \\
\mathrm{CP}\end{array}$ & $\begin{array}{l}\mathrm{LS} \\
\mathrm{DF}\end{array}$ & $\begin{array}{l}-4.1 \pm 1.1 \\
-4.0 \pm 1.1\end{array}$ & $\begin{array}{l}-2.5 \pm 0.6 \\
-2.1 \pm 2.5\end{array}$ & - & None \\
\hline $\begin{array}{l}\text { Plotkin et al. } \\
\text { (2006) }\end{array}$ & $\begin{array}{l}0.75 \mathrm{mg} / \mathrm{kg} / \text { day for } 2 \text { days } \\
\text { every } 4 \text { mo over } 12 \text { mo }\end{array}$ & 23 & $\begin{array}{l}\text { Severe spastic } \\
\text { quadriplegic CP }\end{array}$ & $\begin{array}{l}\text { LS } \\
\text { FN }\end{array}$ & $\begin{array}{l}-3.8 \pm 1.4 \\
-4.5 \pm 1.2\end{array}$ & $\begin{array}{l}-2.3 \pm 1.2 \\
-2.6 \pm 0.9\end{array}$ & $\begin{array}{l}\text { Increased serum PTH, } \\
\text { Decreased Serum } \\
\text { NTx }\end{array}$ & $\begin{array}{l}\text { One fracture during } \\
\text { treatment }\end{array}$ \\
\hline $\begin{array}{l}\text { Choi et al. }{ }^{11)} \\
(2007)\end{array}$ & $\begin{array}{l}30 \mathrm{mg} / \mathrm{m}^{2} \text { monthly for } 6-37 \\
\mathrm{mo}\end{array}$ & 11 & $\begin{array}{l}\text { Osteogenesis } \\
\text { imperfecta }\end{array}$ & $\begin{array}{l}\text { LS } \\
\text { FN }\end{array}$ & $\begin{array}{l}-2.5 \pm 1.75 \\
-3.7 \pm 0.90\end{array}$ & $\begin{array}{c}1.5 \pm 3.06 \\
-1.77 \pm 0.89\end{array}$ & - & $\begin{array}{l}\text { Decreased } \\
\text { frequency by } \\
0.6 \pm 0.69 / y r\end{array}$ \\
\hline $\begin{array}{l}\text { Lee et al. }{ }^{26)} \\
(2008)\end{array}$ & $\begin{array}{l}0.5 \mathrm{mg} / \mathrm{kg} / \text { day for } 3 \text { days } \\
\text { every } 6-8 \text { wk (total } 6-8 \\
\text { cycles) }\end{array}$ & 9 & $\begin{array}{l}\text { NF1, epilepsy, } \\
\text { autoimmune } \\
\text { disease, } \\
\text { hematologic } \\
\text { malignancy }\end{array}$ & $\begin{array}{l}\text { LS } \\
\text { FN }\end{array}$ & $\begin{array}{l}-3.91 \pm 1.79 \\
-3.71 \pm 1.83\end{array}$ & $\begin{array}{l}1.86 \pm 1.18 \\
-2.53 \pm 1.77\end{array}$ & $\begin{array}{l}\text { Decreased total serum } \\
\text { calcium }(P=0.008), \\
\text { phosphorus } \\
(P=0.015)\end{array}$ & None \\
\hline $\begin{array}{l}\text { Baroncelli et } \\
\text { al. }^{23)}(2013)\end{array}$ & $\begin{array}{l}0.5-1 \mathrm{mg} / \mathrm{kg} / \text { day for } 3 \\
\text { consecutive days for mean } \\
7.3 \pm 1.1 \mathrm{yr}\end{array}$ & 9 & $\begin{array}{l}\text { Idiopathic juvenile } \\
\text { osteoporosis }\end{array}$ & LS & $-3.8 \pm 0.4$ & $-0.7 \pm 0.3$ & - & $\begin{array}{l}\text { Decreased fracture } \\
\text { rate }\end{array}$ \\
\hline$\underset{(2016)}{\operatorname{Lim} \text { et al. }}$ & $\begin{array}{l}0.5 \mathrm{mg} / \mathrm{kg} / \text { day for } 3 \\
\text { consecutive days every } 6 \\
\text { wk over } 6 \text { mo }\end{array}$ & 9 & Osteosarcoma & LS & $-2.14 \pm 0.94$ & $-1.76 \pm 0.95$ & - & $\begin{array}{l}\text { Two fractures after } \\
\text { discontinuation } \\
\text { of treatment }\end{array}$ \\
\hline $\begin{array}{l}\text { Moon et al. }{ }^{27)} \\
(2017)\end{array}$ & $\begin{array}{l}0.25-0.5 \mathrm{mg} / \mathrm{kg} / \text { day, first } \\
\text { day } 0.5-1.0 \mathrm{mg} / \mathrm{kg} / \text { day, } \\
2 \text { consecutive days every } \\
3-4 \text { mo over } 6-12 \mathrm{mo}\end{array}$ & 10 & Quadriplegic CP & LS & $-4.2 \pm 1.2$ & $-2.6 \pm 1.6$ & $\begin{array}{l}\text { Decreased serum ALP, } \\
\text { increased vitamin D }\end{array}$ & None \\
\hline $\begin{array}{c}\text { The present } \\
\text { study (2020) }\end{array}$ & $\begin{array}{l}1 \mathrm{mg} / \mathrm{kg} / \text { day for } 3 \\
\text { consecutive days every } 4 \\
\text { mo over } 12 \mathrm{mo}\end{array}$ & 13 & $\begin{array}{l}\text { Secondary } \\
\text { osteoporosis due } \\
\text { to immobilization, } \\
\text { steroid treatment, } \\
\text { idiopathic juvenile } \\
\text { osteoporosis }\end{array}$ & $\begin{array}{l}\text { LS } \\
\text { FN }\end{array}$ & $\begin{array}{l}-3.8 \pm 1.4 \\
-5.7 \pm 2.4\end{array}$ & $\begin{array}{l}-1.6 \pm 1.9 \\
-3.6 \pm 3.0\end{array}$ & - & $\begin{array}{l}\text { One fracture during } \\
\text { treatment }\end{array}$ \\
\hline
\end{tabular}

$\overline{B M D}$, bone mineral density; SD, standard deviation; LS, lumbar spine; ALP, alkaline phosphatase; NTx, N-terminal telopeptide; CP, cerebral palsy; DF, distal femur; FN, femur neck; PTH, parathyroid hormone; NF1, neurofibromatosis type 1. 
significant decrease in serum levels of calcium and phosphorus was detected in the absence of supplementation with calcium and vitamin D after pamidronate therapy. One-third of the participants showed symptomatic hypocalcemia, but their symptoms were relieved by supplementation with calcium and vitamin $\mathrm{D}^{26)}$ Therefore, calcium and vitamin $\mathrm{D}$ supplementation has become a widespread practice for preventing hypocalcemia during treatment with pamidronate. ${ }^{4)}$ Pamidronate treatment can cause an increase in $25(\mathrm{OH})_{2} \mathrm{D}_{3}$ level and a decrease in alkaline phosphatase $\mathrm{e}^{27)}$; however, no significant changes in biochemical parameters were detected in the present study.

A previous study showed that stored bisphosphonates maintained their biological activity at least 2 years after discontinuation of pamidronate infusions. ${ }^{7)}$ In the present study, lumbar spine and femoral neck BMD $z$-scores were maintained within the normal range after discontinuation of pamidronate. In particular, participant No. 12, who had IJO and was not in a bedridden state, showed significantly improved femoral neck BMD $z$-score after discontinuation of treatment.

No significant adverse events occurred during pamidronate infusion in our study. However, other studies have reported acute phase reactions, including fever, malaise, vomiting, abdominal pain, and muscle or bone pain, within one to 3 days after initiation of treatment. ${ }^{7)}$ Retention of highaffinity bisphosphonates and long-term suppression of bone turnover and remodeling are major long-term concerns in this population, although recovery of recycled bisphosphonates from bone occurs over a shorter period in pediatric than in adult patients due to the higher bone turnover rate in children. ${ }^{7)}$ Persistent low bone remodeling activity after discontinuation of bisphosphonates can interfere with normal bone shaping and repair during growth ${ }^{28)}$ Bisphosphonates also can cross the placenta, so any drugs remaining in bone tissues at adulthood can affect fetal development during pregnancy. ${ }^{7)}$ Therefore, further studies are required to better define the long-term safety of pamidronate therapy in pediatric patients.

Our study had several limitations. It was a retrospective study with a small number of patients, so issues arose due to missing data and variable follow-up durations among the patients. During the follow-up period, bone pain and changes in quality of life could not be assessed because of lack of data. In addition, this study included consecutive patients who were referred to a pediatric endocrinology clinic at a single institute, which led to sampling bias. Bone turnover markers can be helpful in monitoring the efficacy of treatment. ${ }^{29)}$ Previous studies have reported an increase in serum osteocalcin (which reflects increased bone formation) and a decrease in urine $\mathrm{N}$-terminal telopeptide (which indicates decreased bone resorption) during pamidronate treatment. ${ }^{27)}$ However, no bone turnover markers were included in the present study due to lack of data.

In conclusion, this study demonstrated that pamidronate treatment increased lumbar spine and femoral neck BMD values in pediatric patients with osteoporosis without significant adverse events. The lumbar spine BMD $z$-scores increased depending on duration of pamidronate treatment. A bedridden state and malnutrition were risk factors for poor response to pamidronate. Further studies with larger numbers of patients are required to define better the frequency of osteoporosis and the long-term efficacy and safety of pamidronate therapy in children.

\section{Ethical statement}

This study was approved by the Institutional Review Board (IRB) of Asan Medical Center in Seoul, Korea (IRB No. 20201037).

\section{Conflict of interest}

No potential conflict of interest relevant to this article was reported.

\section{Acknowledgments}

This study was supported by the Basic Science Research Program through the National Research Foundation of Korea (NRF) funded by the Ministry of Education (2017R1D1A1B03029638).

\section{References}

1. Marrani E, Giani T, Simonini G, Cimaz R. Pediatric osteoporosis: diagnosis and treatment considerations. Drugs 2017;77:679-95.

2. Shuhart CR, Yeap SS, Anderson PA, Jankowski LG, Lewiecki EM, Morse LR, et al. Executive summary of the 2019 ISCD Position Development Conference on Monitoring Treatment, DXA Cross-calibration and Least Significant Change, Spinal Cord Injury, Peri-prosthetic and Orthopedic Bone Health, Transgender Medicine, and Pediatrics. J Clin Densitom 2019;22:453-71.

3. Arundel P, Bishop N. Primary osteoporosis. Endocr Dev 2015;28:162-75.

4. Ward LM, Konji VN, Ma J. The management of osteoporosis in children. Osteoporos Int 2016;27:2147-79.

5. Bianchi ML. Osteoporosis in children and adolescents. Bone 2007;41:486-95.

6. Russell RG. Bisphosphonates: mode of action and pharmacology. Pediatrics 2007;119 Suppl 2:S150-62.

7. Eghbali-Fatourechi G. Bisphosphonate therapy in pediatric patients. J Diabetes Metab Disord 2014;13:109.

8. Glorieux FH, Bishop NJ, Plotkin H, Chabot G, Lanoue G, Travers R. Cyclic administration of pamidronate in children with severe osteogenesis imperfecta. N Engl J Med 1998;339:947-52.

9. Henderson RC, Lark RK, Kecskemethy HH, Miller F, Harcke HT, Bachrach SJ. Bisphosphonates to treat osteopenia in children with quadriplegic cerebral palsy: 
a randomized, placebo-controlled clinical trial. J Pediatr 2002;141:644-51.

10. Acott PD, Wong JA, Lang BA, Crocker JF. Pamidronate treatment of pediatric fracture patients on chronic steroid therapy. Pediatr Nephrol 2005;20:368-73.

11. Choi JH, Shin YL, Yoo HW. Short-term efficacy of monthly pamidronate infusion in patients with osteogenesis imperfecta. J Korean Med Sci 2007;22:209-12.

12. Lim SW, Ahn JH, Choi A, Cho WH, Lee JA, Kim DH, et al. Efficacy of pamidronate in pediatric osteosarcoma patients with low bone mineral density. Ann Pediatr Endocrinol Metab 2016;21:21-5.

13. Rauch F, Munns CF, Land C, Cheung M, Glorieux FH. Risedronate in the treatment of mild pediatric osteogenesis imperfecta: a randomized placebo-controlled study. J Bone Miner Res 2009;24:1282-9.

14. Ooi HL, Briody J, McQuade M, Munns CF. Zoledronic acid improves bone mineral density in pediatric spinal cord injury. J Bone Miner Res 2012;27:1536-40.

15. Kim JH, Yun S, Hwang SS, Shim JO, Chae HW, Lee YJ, et al. The 2017 Korean National Growth Charts for children and adolescents: development, improvement, and prospects. Korean J Pediatr 2018;61:135-49.

16. Lim JS, Hwang JS, Lee JA, Kim DH, Park KD, Cheon GJ, et al. Bone mineral density according to age, bone age, and pubertal stages in korean children and adolescents. J Clin Densitom 2010;13:68-76.

17. Kang MJ, Hong HS, Chung SJ, Lee YA, Shin CH, Yang SW. Body composition and bone density reference data for Korean children, adolescents, and young adults according to age and sex: results of the 2009-2010 Korean National Health and Nutrition Examination Survey (KNHANES). I Bone Miner Metab 2016;34:429-39.

18. Fan B, Lu Y, Genant H, Fuerst T, Shepherd J. Does standardized BMD still remove differences between Hologic and GE-Lunar state-of-the-art DXA systems? Osteoporos Int 2010;21:1227-36.

19. Dwan K, Phillipi CA, Steiner RD, Basel D. Bisphosphonate therapy for osteogenesis imperfecta. Cochrane Database Syst Rev 2014;10:CD005088.

20. Saraff V, Hogler W. Endocrinology and adolescence: osteoporosis in children: diagnosis and management. Eur J Endocrinol 2015;173:R185-97.

21. Jung KJ, Kwon SS, Chung CY, Lee KM, Sung KH, Cho BC, et al. Association of gross motor function classification system level and school attendance with bone mineral density in patients with cerebral palsy. J Clin Densitom 2018;21:5016.

22. Grissom LE, Kecskemethy HH, Bachrach SI, McKay C, Harcke HT. Bone densitometry in pediatric patients treated with pamidronate. Pediatr Radiol 2005;35:511-7.

23. Baroncelli GI, Vierucci F, Bertelloni S, Erba P, Zampollo E, Giuca MR. Pamidronate treatment stimulates the onset of recovery phase reducing fracture rate and skeletal deformities in patients with idiopathic juvenile osteoporosis: comparison with untreated patients. J Bone Miner Metab 2013;31:533-43.

24. Ward L, Tricco AC, Phuong P, Cranney A, Barrowman $\mathrm{N}$, Gaboury I, et al. Bisphosphonate therapy for children and adolescents with secondary osteoporosis. Cochrane Database Syst Rev 2007;(4):CD005324.

25. Plotkin H, Coughlin S, Kreikemeier R, Heldt K, Bruzoni M, Lerner G. Low doses of pamidronate to treat osteopenia in children with severe cerebral palsy: a pilot study. Dev Med Child Neurol 2006;48:709-12.

26. Lee YA, Lim JS, Shin CH, Yang SW. Pamidronate therapy in children and adolescents with osteoporosis. Horm Res 2008;70:27.

27. Moon SJ, An YM, Kim SK, Kwon YS, Lee JE. The effect of low-dose intravenous bisphosphonate treatment on osteoporosis in children with quadriplegic cerebral palsy. Korean J Pediatr 2017;60:403-7.

28. Rauch F, Glorieux FH. Osteogenesis imperfecta. Lancet 2004;363:1377-85.

29. Swaminathan R. Biochemical markers of bone turnover. Clin Chim Acta 2001;313:95-105. 